Published in final edited form as:

Neuroscientist. 2014 October ; 20(5): 546-562. doi:10.1177/1073858414525828.

\title{
The Neurobiology of Cancer Pain
}

\author{
Brian L. Schmidt ${ }^{1,2,3}$ \\ ${ }^{1}$ Department of Oral Maxillofacial Surgery, New York University College of Dentistry, New York, \\ NY, USA \\ 2Department of Neuroscience \& Physiology, New York University School of Medicine, New York, \\ NY, USA \\ ${ }^{3}$ Bluestone Center for Clinical Research, New York University, NY, USA
}

\begin{abstract}
The global burden of cancer pain is enormous and opioids, despite their side effects, remain the primary therapeutic approach. The cause of cancer pain is unknown. Mechanisms driving cancer pain differ from those mechanisms responsible for inflammatory and neuropathic pain. The prevailing hypothesis put forward to explain cancer pain posits that cancers generate and secrete mediators which sensitize and activate primary afferent nociceptors in the cancer microenvironment. Moreover, cancers induce neurochemical reorganization of the spinal cord, which contributes to spontaneous activity and enhanced responsiveness. The purpose of this review, which covers clinical and preclinical studies, is to highlight those peripheral and central mechanisms responsible for cancer pain. The challenges facing neuroscientists and clinicians studying and ultimately treating cancer pain are discussed.
\end{abstract}

\section{Keywords}

cancer pain; cancer; tumor; pain; sensory system

The global burden of cancer pain is enormous. Patients are living longer with cancer and many endure cancer pain for extended durations. The etiology of cancer pain remains unknown. Accordingly, a targeted approach to cancer pain remains elusive. In this article, I review the pain-producing mechanisms secondary to cancer. I do not review pain that results from cancer treatment, that is, pain resulting from radiation, chemotherapy, or surgery. The pain-producing mechanisms I review pertain to cancer patients prior to treatment or after failed treatment. This latter group of cancer patients includes those patients with viable carcinoma; carcinoma in some patients can be controlled for years.

\footnotetext{
(C) The Author(s) 2014

Corresponding Author: Brian L. Schmidt, Bluestone Center for Clinical Research, New York University College of Dentistry, 421 First Avenue, 233W, New York, NY 10010, USA. bls322@nyu.edu.

Reprints and permissions: sagepub.com/journalsPermissions.nav

Declaration of Conflicting Interests

The author(s) declared no potential conflicts of interest with respect to the research, authorship, and/or publication of this article.
} 
The prevailing hypothesis put forward to explain cancer pain posits that cancers generate and secrete mediators. These putative mediators subsequently sensitize and activate primary afferent nociceptors in the cancer microenvironment. Cancer pain has been proposed to result from tissue destruction and nerve compression; however, this hypothesis is not consistent with clinical findings or with preclinical data. Cancer pain has also been described as inflammatory pain. However, non-steroidal anti-inflammatory drugs are clinically ineffectual. Moreover, preclinical studies provide ample evidence that cancer pain is distinguishable from inflammatory pain and is generally a unique form of pathologic pain.

Cancers exhibit phenotypic and genomic heterogeneity. These unpredictable differences throw up challenges to clinicians and scientists alike. Pain in patients varies by the histologic type of cancer, the site involved (i.e., primary versus metastatic sites), and whether the involved site is required for musculoskeletal function. Histologically different cancers involving disparate anatomic sites produce a different pain phenotype (Figure 1). This finding is not only a clinical observation but aligns with findings from preclinical models that have been generated using different histologic types of cancer (e.g., sarcoma, melanoma, and adenocarcinoma). Different cancers inoculated into the same anatomic site produce different pain related behavior. These different types of cancer also produce distinct neurochemical reorganization of the spinal cord (Sabino and others, 2003). While the prevalence of cancer pain depends on the histologic type and anatomic site, more than 50\% of cancer patients experience pain (van den Beuken-van Everdingen and others, 2007) (Figure 2).

I first review the relevant clinical studies and the scientific findings in these investigations that extend our understanding of the etiology of cancer pain. I then review the preclinical studies and summarize the scientific findings about the etiology of cancer pain garnered from animal models.

\section{Clinical Studies}

While clinical studies and trials can provide insight into the basic mechanisms of disease, most clinical trials on cancer pain lend limited insight into the neurobiology of cancer pain. The investigators who design and conduct these trials should be commended; cancer pain trials are of the most difficult clinical studies. The medical condition of patients with latestage cancer makes recruitment challenging. Dosing of experimental drugs in this population can be difficult. A few of the clinical trials that do provide information regarding possible mechanisms will be reviewed.

\section{Ketamine}

Ketamine, an $N$-methyl-D-asparate (NMDA) receptor antagonist, and opioids have been combined and tested in cancer pain patients. The approach of NMDA receptor blockade is supported by preclinical cancer models that suggest that NMDA receptor activity, as measured by receptor phosphorylation, facilitates bone cancer pain ( $\mathrm{Gu}$ and others 2010; Zhang and others 2008). Two randomized controlled trials that met appropriate Cochrane criteria concluded that ketamine improves the effectiveness of morphine in the treatment of cancer pain (Bell and others 2012). These results suggest that human cancers might be 
secreting mediators that activate the NMDA receptor leading to sensory neuron sensitization or activation. Also, possibly by antagonizing the NMDA receptor in the setting of cancer opioid receptors retain their sensitivity to opioid agonists.

\section{Opioids}

Opioids, which can be delivered to patients by multiple routes, are the most commonly used and most effective analgesics for the management of cancer pain. Clinical trials that address the effectiveness of opioids for cancer pain are the most comprehensive. Four studies, which met the design criteria for Cochrane review measured the analgesic effect of opioids in cancer patients (Zeppetella and Davies 2013). All four studies looked at the use of oral transmucosal fentanyl citrate for the management of breakthrough cancer pain. Titration of oral transmucosal fentanyl citrate was the focus of one study while another study compared oral transmucosal fentanyl citrate with morphine. In a third study, oral transmucosal fentanyl citrate was compared with placebo. Oral transmucosal fentanyl citrate was shown to be effective for management of breakthrough cancer pain; it lowered pain intensity and increased pain relief at each of the time points. Global assessment also showed oral transmucosal fentanyl citrate to be effective. While the conclusion is that oral transmucosal fentanyl citrate can be effective for the management of breakthrough cancer pain, clinicians should remember that genetic variation in the catechol- $O$-methyltransferase gene affects cancer patients' response to morphine, which might explain the non-responding patient (Rakvag and others, 2008).

There are a number of drawbacks with opioids, including tolerance following administration of escalating doses. Practitioners, patients, and family caregivers are often faced with concern for addiction in patients requiring treatment for cancer pain; however, addiction is rarely a problem in cancer patients. Studies in preclinical cancer mice have demonstrated that there are decreased motivational properties of morphine in cancer mouse models. Using the place preference paradigm investigators have demonstrated that mice suffering from cancer pain do not develop a preference for the environment associated with morphine (Betourne and others 2008). The authors proposed that secretion of anti-opioid neuropeptides within the nucleus accumbens contributed to decreased reward associated with morphine.

\section{Spinal Cord Stimulation}

Cancer pain leads to pathologic changes in the spinal cord. Spinal cord stimulation (SCS) using electrotherapy has been proposed as an approach to reverse pathology-induced neurochemical changes in the dorsal horn. SCS has been used for difficult neuropathic pain conditions such as complex regional pain syndrome and has been investigated for cancer pain. While no randomized clinical trials are available, four clinical studies with a total of 92 participants have been published (Lihua and others 2013). In these studies the investigators reported pain scores before-and-after SCS. In two studies, pain relief was achieved in more than three quarters of patients by the end of the follow-up period. In all four of the studies, analgesic use was reduced. There are rare side effects associated with SCS; infection at the site of probe placement is most common. While efficacy is suggested based on these limited 
studies no conclusive recommendation can be made with regard to the use of SCS in cancer pain patients.

\section{Acupuncture}

Acupuncture has been investigated for the management of cancer pain. While human studies have demonstrated that acupuncture is effective in reducing cancer pain, effective controls for acupuncture studies are nearly impossible (Paley and others 2011). Therefore, the results of acupuncture for cancer pain are difficult to assess. Electroacupuncture (EA) produces antinociception in female and male cancer mice; however, the effect in males does not last as long as in females (Smeester and others 2012). An experimental strength of this study is that the authors studied two separate cancer mouse models, a fibrosarcoma and an osteosarcoma. The authors use cells syngeneic with the mouse lines; therefore, the model does not suffer from the drawbacks of using athymic mice. When athymic mice are used for the orthotopic mouse model the role of cell-mediated immunity in cancer pain is lost. EA is antinociceptive in both cancer models. EA significantly reduces neutrophil count and $\mathrm{PGE}_{2}$ within the cancer microenvironment. While multiple mechanisms for acupuncture are proposed this work demonstrates that an anti-inflammatory effect contributes to the reduction in cancer pain. However, to demonstrate cause and effect of EA on inflammation in this cancer model, a pharmacological approach is required.

\section{Preclinical Studies}

\section{Interpretation and the Translational Potential of Preclinical Cancer Pain Studies}

Cancer pain is a complex pathologic process. Cancer cells produce mediators that recruit and affect other cells within the cancer microenvironment, including nerves and immune cells. Cancer pain involves interactions and crosstalk between the cancer, the primary afferent nociceptor, and the immune system. Cancer induces plasticity in the peripheral and central nervous system. Cancer-evoked responses in rodent models mirror some of the changes seen clinically.

When evaluating the results from preclinical cancer pain models, the reader should consider the following: (1) the proliferative, invasive, and metastatic potential of the cell line; (2) the anatomic site that is inoculated and how closely the site relates to where patients develop cancer; (3) the behavioral test that is used and its relevance to human reports of pain; (4) whether the behavioral test is reflexive or operant; (5) the genetic profile of the animal; and (6) the time between cancer inoculation and the behavioral measurement. More complex factors such as social interaction and environmental enhancement, which are difficult to control across studies, will also impact on cancer growth and pain behavior (Cao and others 2010, Vachon and others 2013). Most cancer pain models, whether bone or soft tissue exhibit heat hyperalgesia and mechanical allodynia.

Similar to most pain studies, the preclinical tests used in cancer models often do not align with the complaints of patients. For example, how often does a patient with either a primary or metastatic cancer in the femur complain of heat hyperalgesia in the foot? Yet, heat hyperalgesia is a common reported finding in bone cancer models. Because of the high prevalence of bone cancer pain the most common rodent cancer pain model is generated by 
inoculating cancer cells into a long bone. This model requires surgical manipulation including an arthrotomy; therefore, post-surgical pain might have an impact on the tested behavior. In a cancer pain model the control should include inoculation of the benign counterpart of the cancer. For example, if squamous cell carcinoma is inoculated, an approach used to create a soft tissue cancer model, then benign keratinocytes should be inoculated. Inoculation of benign keratinocytes in the region of a nerve leads to hypersensitivity (Radtke and others 2010). A rarely used, but clinically relevant and worthwhile model is an abdominal carcinomatosis model in which carcinoma cells are inoculated into the abdomen. The measured behavior is abdominal mechanical allodynia or hunching behavior. A limitation which needs to be considered when interpreting the results of preclinical cancer pain studies is that for most of the published studies a single cancer cell line is used to produce the model. Because of the phenotypic and genotypic heterogeneity of cancers within a single histologic type the applicability of the molecular and behavioral results are limited.

\section{Cancer Pain Is Distinct from Inflammatory Pain and Neuropathic Pain}

Cancer pain is often cited incorrectly as inflammatory pain; evidence from clinical studies and preclinical models strongly suggest that cancer pain can exist in a sterile tissue environment. Compelling evidence that cancer pain is not inflammatory pain is the meager evidence supporting the role of non-steroidal anti-inflammatory drugs; their role in clinical management of cancer pain is often considered controversial (Mercadante and Giarratano 2013). Cancer pain, as compared to inflammatory and neuropathic pain, induces a distinct set of neurochemical changes in the spinal cord and sensory neurons (Honore and others, 2000). Spinal cord plasticity in inflammatory pain is characterized by increased expression of the following: substance $\mathrm{P}$, substance $\mathrm{P}$ receptor, calcitonin gene-related peptide (CGRP), and protein kinase $\mathrm{C} \gamma$. In the neuropathic pain model spinal cord plasticity is characterized by decreased substance $\mathrm{P}$, decreased CGRP, increased galanin and increased neuropeptide Y. In a bone sarcoma mode, spinal cord plasticity is characterized by spinal astrocyte hypertrophy, increased c-Fos expression, and an increase in dynorphin (DYN)immunoreactive neurons. In a cancer model that is produced by implanting fibrosarcoma cells into and around the mouse calcaneous bone wide dynamic range dorsal horn neurons are sensitized to mechanical, heat and cold stimuli, electrophysiologic findings that differ from those found in inflammatory and neuropathic models. High threshold nociceptive neurons are not sensitized in the cancer model (Khasabov and others 2007).

Subtle differences in activation of spinal cord microglia and astrocytes differentiate cancer pain from neuropathic pain. Transient microglial activation and prolonged astrocyte proliferation is a hallmark of neuropathic pain and represents a critical step toward spinal cord plasticity. In two separate cancer pain models cancer astrocyte activation occurs independently of microglial activation (Hald and others 2009). Spinal GFAP expression is reduced with a synthetic cannabinoid agonist (i.e., WIN 55, 212-2) in a cancer pain model but not a neuropathic pain model (Hald and others 2008)

Cancer induces decreased expression of the $\mu$-opioid receptor on dorsal root ganglia (DRG), which is a distinguishing feature between cancer pain and inflammatory pain (Yamamoto 
and others 2008). In a preclinical cancer model the intensity of cancer pain is greater than inflammatory pain; the morphine $\mathrm{ED}_{50}$ for the cancer pain model is three times that for the carrageenan-injected mice (Wacnik and others 2003). Finally, cancer pain and inflammatory pain have been distinguished using a pharmacologic approach (Harano and others 2010). Additional preclinical models of cancer pain demonstrate differences between cancer pain and inflammatory pain (Shimoyama and others 2002).

\section{Cannabinoids and the Endogenous Cannabinoid System}

Cannabinoids have been studied extensively in different cancer pain models, including the following: a bone cancer model produced by inoculating a murine fibrosarcoma cell line into the humerus, femur, tibia, or calcaneus bone of mice; a bone cancer model produced by inoculating osteosarcoma or melanoma cells in the mouse tibia; a bone cancer model produced by inoculating breast carcinoma cells in the rat tibia; and a soft tissue cancer model produced by inoculating human oral squamous cell carcinoma cells into the mouse paw. Both cannabinoid receptor subtypes (i.e., $\mathrm{CBr} 1$ and $\mathrm{CBr}$ 2) have analgesic roles in the cancer models. In preclinical models $\mathrm{CBr}$ agonists reverse cancer-induced pain with similar efficacy to opiates. Both $\mathrm{CBr} 1$ and $\mathrm{CBr} 2$ play roles at the periphery and spinal levels.

Cannabinoids potentially exert their antinociceptive action through reduced tumor burden, limitation of inflammatory mediators, endogenous opioid secretion, receptor and ion channel function in either primary afferent nociceptors or central neurons. There has been some question as to the role of the $\mathrm{CBr} 1$ and $\mathrm{CBr} 2$ receptors in the cancer microenvironment. Activation of peripheral $\mathrm{CBr} 2$ receptors reduce cancer burden and reduce cancer pain (Guerrero and others 2008; Lozano-Ondoua and others 2010; Saghafi and others 2011). In a fibrosarcoma mouse model, both $\mathrm{CBr} 1$ and $\mathrm{CBr} 2$ receptors have an antinociceptive role (Khasabova and others 2011b). Both $\mathrm{CBr} 1$ and $\mathrm{CBr} 2$ agonists reduce cancer-induced mechanical allodynia; co-injection of the two agonists have a synergistic effect which is independent of an opioid mechanism. Previously, Khodorova demonstrated that activation of $\mathrm{CBr} 2$ receptors on keratinocytes leads to opioid secretion (Ibrahim and others 2005). The neurobiologic actions of $\mathrm{CBr}$ agonists in cancer pain likely include (1) $\mathrm{CBr} 1$-mediated spinal presynaptic inhibition (Furuse and others 2009); (2) CBr1-mediated peripheral afferent nociceptor inhibition (Kehl and others 2003; Hamamoto and others 2007, Guerrero and others 2008; Potenzieri and others 2008); (3) CBr2-mediated spinal NMDA receptor regulation (Gu and others 2011); (4) CBr2-mediated spinal opioid secretion (Curto-Reyes and others, 2010); (5) peripheral CBr1-mediated opioid secretion; and (6) peripheral CBr2mediated opioid secretion (Curto-Reyes and others 2010; Guerrero and others 2008; Saghafi and others 2011).

An attractive strategy for the treatment of cancer pain is to exploit the endogenous analgesic system in the cancer microenvironment with opioids and cannabinoids. Preclinical studies suggest that the peripheral endocan-nabinoid system is a promising target for managing bone cancer pain (Khasabova and others 2011a). A local peripheral increase of 2arachidonoyl glycerol (2AG) decreases mechanical hyperalgesia secondary to fibrosar-coma inoculated into the calcaneus bone. Activation of peripheral $\mathrm{CBr} 2$ receptors but not $\mathrm{CBr} 1$ receptors produces analgesic efficacy similar to morphine. There is an increase in $\mathrm{CBr} 2$ 
receptors in the plantar skin over the paw tumor. In a similar bone cancer pain model cutaneous hyperalgesia depends on the level of anandamide (AEA) in the paw skin. Fatty acid amide hydrolase (FAAH) activity and mRNA in the DRG ipsilateral to the affected paw contributes to increased FAAH activity in cancer microenvironment. The anti-hyperalgesia action of AEA and FAAH inhibition is blocked by a CBr1 antagonist. AEA and FAAH inhibition affects calcium ion transduction, which the investigators measured in DRG neurons co-cultured with fibrosarcoma cells (Khasabova and others 2008). The co-culture system provides a strategic experimental approach to understand the electrophysiologic response of neurons to mediators that are secreted by cancer. Reduced binding of AEA to FAAH is analgesic in a cancer pain model (Khasabova and others 2013). These preclinical studies reinforce that cannabinoids remain a good target for control of cancer pain and have shown promise in clinical studies (Portenoy and others 2012).

\section{Secretion of Mediators by the Cancer That Sensitize or Activate Primary Afferent Neurons}

The prevailing hypothesis for cancer pain is that cancers produce and secrete algogenic mediators that sensitize and/or activate primary afferent nociceptors within the cancer microenvironment (Figure 3). A formidable challenge in studying cancer pain research is the dynamic and complex interaction of cells within the cancer microenvironment. Carcinogenesis involves the recruitment of neurons, lymphocytes, endothelial and fibroblasts to the cancer microenvironment, which then secrete pain-modulating mediators.

Much of our evidence that mediators contribute to pain is based on a change in pain behavior following administration of an antagonist. While a drug might have an antinociceptive effect in a cancer pain model, the drug might also involve a reduction in cancer proliferation. Reduced cancer proliferation would reduce cancer burden and decrease the amount of algogenic mediators secreted by the cancer. Therefore, investigators are encouraged to measure the anti-proliferative effect of a drug, either in vitro or in vivo but preferably both, along with the antinociceptive effect. Some of the key mediators that contribute to cancer pain will be reviewed below.

\section{Neurotrophic Factors}

Neurotrophic factors, which can be secreted by the cancer or constituent cells in the cancer microenvironment, contribute to cancer pain, perineural invasion, and locoregional recurrence. Different cancers express and secrete different neurotrophic factors and also express their cognate receptors. Breast cancer expresses brain-derived neurotrophic factor (BDNF) and neurotrophin-4/5 (Vanhecke and others 2011). The best described neurotrophic factor that has a role in cancer pain is nerve growth factor (NGF). Oral squamous cell carcinoma produces NGF and neurturin (Ye and others 2012). The source of NGF in the cancer microenvironment could be the carcinoma itself (Ye and others 2011). Constituent cells can also secrete NGF, which is the case with prostate cancer (Halvorson and others 2005). NGF sequestration with an antibody is highly effective in reversing cancer pain in pre-clinical cancer models (Mantyh and others 2010; Ye and others 2011). In a mouse bone sarcoma pain model anti-NGF reverses cancer-induced changes in the spinal cord (Sevcik and others 2005). In this model, anti-NGF does not have an effect on cancer progression nor does anti-NGF affect sensory or sympathetic innervation of the cancer in the bone or 
overlying skin. On the other hand, sensory nerve sprouting occurs in an orthotopic breast cancer model; NGF is expressed and secreted by the breast cancer cells and associated stromal cells. Sensory fibers that are $\mathrm{CGRP}^{+} / \mathrm{Trk} \mathrm{A}^{+} / \mathrm{GAP} 3^{+}$sprout (Bloom and others 2011). Anti-NGF reverses spinal cord markers consistent with spinal cord plasticity, including DYN and c-Fos expression (Jimenez-Andrade and others 2011). In a soft tissue oral squamous cell carcinoma model, anti-NGF reduces cancer pain, cancer progression and cachexia (Ye and others 2011). Cancers are notoriously vascular. The processes of angiogenesis and neurogenesis have overlapping signaling pathways (Nico and others 2008). In certain models NGF secretion by the cancer induces both angiogenesis and neurogenesis (Mapp and Walsh 2012) (Figure 4). Angiogenesis and perivascular nerve growth are linked in a prostate cancer bone metastasis model (Jimenez-Andrade and others 2011). However, this finding is not upheld in all cancer models. In a mouse cancer model that is produced by inoculating fibrosarcoma cells into the hindpaw there is an increase in $\mathrm{CGRP}^{+}$nerve fibers and a decrease in CD- $31^{+}$blood vessels (Wacnik and others, 2005).

\section{ATP}

One of the early studies demonstrating the role of ATP and the $\mathrm{P} 2 \mathrm{X}_{3}$ receptor in cancer pain uses a fibrosarcoma bone (calcaneous) cancer mouse model (Gilchrist and others 2005). The authors analyze the neuronal population in the skin overlying the tumor: $\mathrm{P} 2 \mathrm{X}_{3}$ expression increases in $\mathrm{CGRP}^{+}$neuronal fibers. Cancer induces $\mathrm{P}_{2} \mathrm{X}_{3}$ receptor up-regulation and electrophysiologic sensitization (i.e., ATP-induced transient current) which increases by more than 50\% (Wu and others 2012). This work uses a rat bone cancer pain model produced by inoculating Walker 256 breast sarcocarcinoma cells. A317491, an antagonist of the $\mathrm{P} 2 \mathrm{X}_{3}$ receptor, attenuates bone cancer pain when injected locally or intrathecally. The $\mathrm{P} 2 \mathrm{X}_{3}$ and $\mathrm{P} 2 \mathrm{X}_{2 / 3}$ receptor antagonist, $\mathrm{AF} 353$, reduces cancer-induced electrical, mechanical, and thermal stimuli evoked dorsal horn hyper excitability (Kaan and others 2010).

Nodose ganglia cocultured with fibrosarcoma cells show that P2X-mediated responses were highly variable and demonstrated biphasic desensitization kinetics with both fast and slow currents (Chizhmakov and others 2009). Inhibition of ATP-activated currents by opioids had a strong dependence on desensitization kinetics. In some neurons sensitivity to opioid agonists was completely lost. These authors used an appropriate, but rarely employed, control: coculturing neurons with rapidly proliferating, but benign, fibroblasts. The neurons that were cocultured with the fibroblasts did not exhibit the desensitization kinetics observed with the neurons cocultured with the cancer. Potentially ATP that is produced at high levels by the cancer and then secreted into the cancer microenvironment could affect opioid responsiveness in cancer patients.

\section{Endothelin}

The role of endothelin-1 (ET-1) was first described in a cancer pain model by Mantyh and his colleagues (Wacnik and others 2001). The role of ET-1 in cancer pain is now well established in multiple cancer pain models. The role of ET-1 in cancer pain is reviewed elsewhere (Hans and others 2009). Recently, an interesting mechanism of ET-1 sensitization of ATP release by endothelium is reported (Joseph and others 2013). Released ATP

Neuroscientist. Author manuscript; available in PMC 2014 October 01. 
activates $\mathrm{P} 2 \mathrm{X}_{2 / 3}$ receptors on nociceptors to induce pain. Given that cancers are characterized by angiogenesis and are highly vascular this is a compelling mechanism potentially contributing to cancer pain (Figures 3 and 4).

\section{Protons}

Cancers generate an acidic microenvironment, which could activate transient receptor potential vanilloid 1 (TRPV1) or acid-sensing ion channels (ASICs). In a bone cancer pain model the acidic microenvironment contributes to ASICs up-regulation and cancer pain behavior (Nagae and others 2007). The role of TRPV1 in cancer pain is demonstrated using pharmacology across a number of cancer pain models (Ghilardi and others 2005; Honore and others 2009; Karai and others 2004; Niiyama and others 2009; Shinoda and others 2008). In a rat bone cancer pain model, TRPV1 on DRGs are overexpressed via formaldehyde (Han and others 2012). Lipophilic substances that activate TRPV1 are secreted by sarcoma cells (Lautner and others 2011). Plasticity within the associated ganglia includes up-regulation of TRPV1 (Asai and others 2005). In a trigeminal cancer pain model that is produced by inoculating squamous cell carcinoma into the gingiva of a rat mechanical allodynia and thermal hyperalgesia occur along with increased expression of CGRP, substance $\mathrm{P}, \mathrm{P} 2 \mathrm{X}_{3}$, and TRPV1 in the associated trigeminal ganglia (Nagamine and others 2006).

\section{Formaldehyde}

Endogenous formaldehyde, which is produced by lysine-specific demethylase 1 (LSD1) in certain cancers, contribute to pain. LSD1 and endogenous formaldehyde are up-regulated in breast and prostate cancer. In a bone cancer pain model produced by inoculating MRMT-1 breast cancer cells in the bone marrow of rats, endogenous formaldehyde is increased in the bone marrow, sera, and tumor tissues of the rat bone cancer pain model. Systemic injection of the LSD1 inhibitor, pargyline, in this cancer pain model reduces cancer pain behavior; pargyline did not have a proliferative effect on the cancer cells (Liu and others 2013).

\section{Proteases}

Cancers produce and secrete proteases, which are responsible for destruction of tissue and expansion of the cancer. Proteases have been measured in the cancer microenvironment of human patients, in cancer cell culture and in the tissues of cancer mouse models (Hardt and others 2011). Moreover, using pharmacologic and genetic approaches the role of protease activated receptor-2 (PAR2) has been demonstrated in cancer pain (Lam and Schmidt 2010; Lam and others 2012).

\section{Miscellaneous Mediators}

There are other algogenic mediators produced by cancers that have not been mentioned above. In an orthotopic mouse lung cancer model the tumor tissue has increased levels of tumor necrosis factor-a (TNFa), interleukin-1 $\beta$ (IL1 $\beta)$, and IL6. TNFa contributes to cancer-induced heat hyperalgesia and nociceptor sensitization (Constantin and others 2008). Bradykinin (BK) also has a role in cancer pain. In a mouse melanoma model BK is secreted by the melanoma and activates both $\mathrm{B}_{1}$ and $\mathrm{B}_{2}$ receptors to produce cancer pain (Fujita and 
others 2010). The $B_{1}$ receptor is implicated in bone cancer pain (Sevcik and others 2005). Granulocyte colony stimulating factor (GCSF) and granulocyte macrophage colony stimulating factor (GMCSF) are secreted into the cancer microenvironment and receptors for these mediators are expressed on peripheral nerves innervating the cancer microenvironment (Bali and others 2013). GMCSF sensitizes nerves in the cancer microenvironment and leads to the release of CGRP. If signaling between cancer and the nerves via GCSF and GMCSF is interrupted there is a decrease in cancer induced pain. Interestingly disruption of the signaling leads to a decrease in cancer growth. This article is one of several recent papers that have shown that activity and crosstalk between cancer and the nerve is involved with cancer proliferation (Brener and others 2009; Feng and others 2011; Mayordomo and others 2012). These results suggest that receptors on primary afferents in the cancer microenvironment could not only be targets for cancer pain but also targets for cancer proliferation.

\section{Interactions between Cancer and Sensory Neurons}

The interaction between cancer and surrounding sensory nerves likely contributes to pain. A classic paper in the cancer pain field is one which is produced by inoculating fibrosarcoma cells in and around the calcaneus bone of a mouse. $\mathrm{C}$ fibers adjacent to the tumor show spontaneous activity and increased response to heat. The animals displayed mechanical hypersensitivity. There is a significant increase in epidermal nerve fibers early during cancer growth. However, with time (16-24 days after implantation) there is a decrease in the epidermal nerve fibers (Cain and others 2001). In a rat bone cancer model the dorsal root ganglia overexpress tetrodotoxin resistant sodium channels NaV1.8 and in NaV1.9 (Qiu and others 2012).

A coculture system of cancer cells and neurons provides an experimental strategy for studying plasticity of neurons following exposure to mediators that are released from cancer. Using this approach, investigators demonstrate changes in sensory neurons, including the release of CC chemokine ligand 2 (CCL2), which results in increases in voltage-gated $\mathrm{Ca}^{2+}$ channels (Khasabova and others 2007). Using a similar non-contact co-culture system, proteases released from squamous cell carcinoma up-regulate PAR2 in neurons (Lam and Schmidt 2010).

Perineural invasion (PNI), first described in head and neck cancer, generates cancer pain (Neumann 1862). The molecular mechanism of PNI, which involves neurotrophic factors, associated receptors and chemokines, are reviewed elsewhere (Bapat and others 2011). Cancers have differing proclivities for perineural invasion (Figure 5). Certain cancers which are notoriously painful, such as head and neck or pancreatic, have high rates of perineural invasion. Neurons are not simply bystanders within the cancer microenvironment and there is clear evidence that cross talk between the cancer and neuron contributes to carcinogenesis (Magnon and others 2013). PNI likely involves a molecular and physical interaction between cancer cells and neurons. Integrins, such as the a6 integrin adhesion receptor, are involved with PNI and mediate interaction between the cancer and peripheral nerves. In a bone cancer model inoculated with human cancer cells that express mutated a6 integrin, the mice show a decrease in bone fractures, a decrease in tumor cell migration within the bone 
and a decrease in cancer pain behavior. These findings are compelling and suggest that by inhibiting urokinase-type plasminogen activator, which cleaves and activate $a 6$ integrin receptor, bone cancer pain could be reduced (King and others 2008).

\section{Spinal Cord Changes}

Cancer induces spinal cord plasticity characterized by the following overexpression of nociceptive mediators and receptors, electrophysiologic changes and glial activation (Figure 6). Mantyh proposes a spinal "neurochemical signature" of bone cancer pain, which includes massive astrocyte hypertrophy, internalization of the substance $\mathrm{P}$ receptor, c-Fos expression in lamina one dorsal horn neurons and increased dynorphin, a prohyperalgesic peptide (Schwei and others 1999). Similar dorsal horn changes (i.e., increase in c-Fos positive cells; up-regulation of substance P, CGRP, and DYN) occur in a mouse sarcoma model in which the sarcoma cells are inoculated into the region of the sciatic nerve, rather than into bone (Shimoyama and others, 2005). In a peritoneal carcinomatosis model generated by inoculating the abdominal cavity of mice with gastric carcinoma cells there is up-regulation of substance $\mathrm{P}$ and an increase in c-Fos positivity in the spinal cord; the model also shows up-regulation of the $\mu$ opiate receptor in the DRG (Suzuki and others 2012). In an orofacial cancer pain model produced by injecting Walker carcinoma sarcoma 256B cells into the vibrissal pads of rats, c-Fos expression in the medullary dorsal horn increases. In this orofacial cancer pain model the rats display mechanical allodynia and have difficulty with ingesting food and have prolonged facial grooming periods. Interestingly in this rat orofacial cancer pain model there is a hyposensitivity to both mechanical and thermal simulation in the center of the tumor; however, hypersensitivity occurs along the tumor front (Ono and others 2009).

The spinal cord neurochemical signature along with the associated behavior in cancer pain models can be pharmacologically reversed. Ibandronate (a bisphosphonate that inhibits osteoclasts), osteoprotegerin and a cyclooxygenase-2 (COX-2) inhibitor decrease the neurochemical signs of central sensitization in a mouse bone sarcoma model (Halvorson and others 2008; Honore and others 2000; Sabino and others 2002). Similar to the effect of ibandronate in a rat bone cancer pain model, risedronate (also a bisphosphonate) decreases bone cancer-related bone destruction, pain related behavior and spinal expression of GFAP in a murine bone cancer pain model (Hald and others 2009). Spinal cord plasticity that occurs in the bone cancer model can also be reversed with radiation to the bone cancer site. This finding is consistent with clinical experience which shows that radiation of the cancer site, whether the cancer is in soft tissue or bone, leads to a reduction in pain. Bone cancerinduced spinal cord plasticity, including glial activity, DYN, COX-2, and chemotactic cytokine receptor (CCR2) expression, are reduced with radiation of the primary site of bone cancer (Vit and others, 2006). In a rat model of tibial bone cancer electroacupuncture reverses cancer-induced neurochemical changes including up-regulation of IL-1 $\beta$. Intrathecal injection of an IL-1 $\beta$ receptor antagonist inhibits cancer-induced hyperalgesia (Zhang and others 2007). Not all forms of analgesic treatment for cancer pain reverse the associated spinal cord pathophysiologic changes. Sustained morphine administration reverses cancer pain behavior in a rat cancer model produced by inoculating MRMT-1 cells. Dorsal horn plasticity, however, remains unchanged (Urch and others 2005). 
C-Jun N-terminal kinase (JNK; a subgroup of the MAPK pathway) activation in both neurons and astrocytes within the spinal cord is associated with bone cancer pain in a rat model created by injecting rat mammary gland carcinoma cells. A JNK inhibitor reduces the cancer-induced mechanical allodynia (Wang and others 2012a). T cell death associated gene eight (TDAG8), which is involved with complete Freund's adjuvant-induced chronic inflammatory pain, contributes to bone cancer pain through the protein kinase A (PKA) signaling pathway. Spinal TDAG8 expression increases in a rat bone (tibia) cancer (Walker 256 cells) model. Administration of H89, a PKA inhibitor, attenuates bone cancer pain in this model (Hang and others 2012). The same rat bone cancer model shows increased expression of spinal CCR2 (Hu and others 2013). Intrathecal anti-CX3CR1 neutralizing antibody in a rat tibial bone cancer (Walker 256 mammary gland carcinoma cells) pain model reduces cancer pain behavior (Yin and others 2010). Intrathecal administration of a $\kappa_{2}$-opioid agonist and IL-10 synergistically reduce bone cancer pain (Kim and others 2011). The role of C-fibers in cancer pain is shown in a rat cancer model using epidurally administered resiniferatoxin (RTX), which leads to long-lasting segmental analgesia (Szabo and others, 1999).

EphrinB-EphB receptor signaling is involved in bone cancer pain and morphine tolerance in the cancer pain model. The Eph receptors are receptor tyrosine kinases, which are involved in progression of human malignancies. EphB receptor signaling is involved in neuropathic pain and pain associated with opiate withdrawal. EphB receptors and the respective ligands ephrinBs mediate spinal cord transmission in the setting of cancer. Spinal inhibition of the EphB1 receptor relieves bone cancer pain and restores morphine induced analgesia in this model; spinal cord neurochemical changes are also reversed (Liu and others 2011). Descending modulation of serotonin-dependent spinal processing contributes to cancerinduced bone pain (Donovan-Rodriguez and others 2006). Intrathecal injection of mGLuR-3 agonists and mGLuR-5 antagonists inhibit spontaneous behavior in a bone cancer pain model that was produced by inoculating the mouse femur with sarcoma cells (Ren and others 2012). WNT signaling in the spinal cord mediates bone cancer pain. In a bone cancer pain model there is an increase in the expression of WNT in the spinal cord dorsal horn neurons as well as primary sensory neurons and astrocytes. WNT signaling activation stimulates production of IL-18, TNFa, NR2B glutamate receptor, and $\mathrm{Ca}^{2+}$-dependent signals through the $\beta$-catenin signaling pathway in the spinal cord. Blockade of WNT signaling in the spinal cord reduces neurochemical alterations consistent with mouse bone cancer pain (Zhang and others 2013). Cancers induce production of other spinal nociceptive mediators which are depicted in Figure 6 (Tong and others 2010).

\section{Cancer-Induced Electrophysiologic Changes in the Spinal Cord}

The cancer-induced molecular changes within the spinal cord result in electrophysiologic changes which are distinct relative to the changes induced by neuropathic or inflammatory pain (Figure 6). In the setting of cancer the receptive field of superficial dorsal home neurons enlarges. In a rat cancer pain model produced with MRMT1 mammary cancer cells dorsal horn neurons undergo changes which contribute to pain: they become hyperexcitable, the ratio of wide dynamic range to nociceptive specific neurons increases, and the wide dynamic range neurons have an increased response to mechanical, thermal and electrical 
(A $\beta-$, C fiber-, and post-discharge evoked response) stimuli. One drawback of this study is that the sham-operated animals are produced by injecting growth media. A proper control consists of inoculation of benign cells rather than cell culture media alone (Urch and others 2003). Gabapentin normalizes hyperexcitable superficial dorsal horn neurons and reduces electrical invoked and mechanical evoked responses in the spinal cord (Donovan-Rodriguez and others 2005). Systemic gabapentin reduces mechanical allodynia in a cancer pain mouse model that is produced by inoculating melanoma into the hind paw; importantly, repeated administration of gabapentin does not induce tolerance (Kuraishi and others 2003).

Electrophysiology demonstrates cancer-induced changes in substantia gelatinosa (lamina II) neurons. In this study adult mice were inoculated with sarcoma into the femur. The mice demonstrated hyperalgesia to mechanical stimuli of the skin of the ipsilateral paw. Lamina II neurons in spinal cord slices were studied using whole cell voltage clamp recording techniques. The substantia gelatinosa neurons exhibited spontaneous excitatory postsynaptic currents (EPSCs). The amplitudes of spontaneous EPSCs increase in cancer bearing mice; however, there are no changes in passive membrane potential of substantia gelatinosa neurons. These findings demonstrate that in the bone cancer pain model spinal synaptic transmission is enhanced and involves $\mathrm{A} \delta$ and $\mathrm{C}$ fibers in the substantia gelatinosa across lumbar levels (Yanagisawa and others 2010).

\section{Spinal Astrocyte Activation}

Cancer activates spinal astrocytes leading to astrocyte hypertrophy and proliferation. Reactive astrogliosis occurs in different cancer pain models (Hald and others 2009; Honore and others 2000; Zhang and others 2005). Spinal glia activation in a murine bone cancer pain model depends on TNFa receptors 1 and 2 (Geis and others 2010). Cancer also leads to molecular changes within astrocytes that contribute to cancer pain. One example is D-amino acid oxidase (DAOO), which is found within spinal cord astrocytes. DAOO catalyzes oxidation of amino acids to hydrogen peroxide. DAAO expression and activity is induced in a rat bone cancer model. Intrathecal injection of siRNA/DAAO reduces mechanical allodynia. Subcutaneous and intrathecal injection of a DAAO inhibitor, CBIO, blocks cancer-induced mechanical allodynia in a dose- and time-dependent manner. Subcutaneous injection of CBIO reduces the production of hydrogen peroxide in the spinal cord and reduces GFAP expression in the spinal cord; moreover, CBIO prevents morphine tolerance when the two drugs are used together (Huang and others 2012). The role of TLR4 on microglia is demonstrated in a rat cancer pain model produced by injection of Walker 256 cells into the tibia. In this model intrathecal administration of TLR 4 siRNA reduces the following: expression of TLR4, expression of spinal microglial markers and proinflammatory cytokines and behavioral hypersensitivity (Lan and others 2010; Li and others 2013).

Cancer-induced spinal glial changes are reversed with the glial modulating agent propentofylline (PPF). In a rat tibial cancer model produced with Walker 256 cells microglia and astrocytes are activated in the spinal cord ipsilateral to the cancer. Intrathecal PPF relieves cancer-induced pain and inhibits activation of spinal glial cells and the expression of glia-associated pro-inflammatory cytokines, including IL-1 $\beta$, IL-6, and TNFa (Yao and 
others 2011). PPF works across spinal segments. The drug suppresses glia activation in a rat orofacial cancer pain model produced with Walker 256 cells (Sago and others 2012). Extracellular signal-regulated kinase (ERK) activation in spinal microglia and astrocytes also mediates cancer-induced bone pain. Activation of ERK1/2 occurs in microglia and astrocytes in this cancer model and intrathecal injection of a selective MEK (ERK kinase) reverses cancer-induced mechanical allodynia (Wang and others 2012b).

\section{Future Directions and Challenges in the Field of Cancer Pain Research}

The ardor of many scientists over the past decade has improved our understanding of cancer pain. These advances have primarily resulted from improved understanding of cancer biology and the interaction between cancers and neurons. We now recognize that cancers and neurons act reciprocally on each other. Adrenergic and cholinergic stimulation are necessary for carcinogenesis in some organs (prostate) (Magnon and others 2013). Additionally, there is overlap between pain-related and cancer apoptotic genes. JNK has been implicated in both tumor growth and cancer pain. Systemic injections of inhibitors of JNK reduce cancer-related mechanical allodynia, heat hyperalgesia, and tumor growth both in vitro and in vivo (Gao and others 2009). TPRV1 activation on astrocytoma induces endoplasmic reticulum-mediated cell death (Stock and others 2012).

Cancer pain will continue to plague patients and become increasingly prevalent as cancer therapy extends the duration that patients are able to live with cancer. Some types of cancers are now often curable (e.g., testicular and certain lymphomas). With the implementation of genomic analysis subsets of previously incurable cancers now exhibit improved cure rates (e.g., non-small lung cancers with ALK gene rearrangement that respond to Crizotinib) (Kwak and others 2010). Survival rates for a handful of cancers including oral cancer have not improved. Unfortunately, oral cancer happens to be notoriously painful; it is arguably the most painful and debilitating type of cancer. Genomic heterogeneity of certain cancers remains one of the most significant challenges for treatment and palliation. Histologically and clinically, certain cancers might appear to be identical; however, at a genomic level they display significant heterogeneity. In addition, the genetic makeup of the host has a great influence on patient response to morphine in the setting of cancer. According to the current prevailing explanation, mediators secreted by painful cancers are the primary cause of pain. If this explanation is correct then histologically similar cancers in the same anatomic location might produce a variety of mediators depending on genomic differences in the tumor. Accordingly a single analgesic therapy is unlikely to exhibit equal efficacy for different cancer types and for cancers in different patients.

Most of the studies reviewed are based on preclinical models. We now recognize that cancer pain in patients is intimately tied to other symptoms, including anxiety, depression, and sleep deprivation in the form of a symptom cluster. Somatic and limbic systems converge and affect pain processing. Characterization of higher order cognitive and emotional processes in preclinical cancer models is difficult. In addition, emotions associated with a painful or rapid demise could alter pain perception and the study of cancer pain. Translating results from preclinical models to patient will subsequently be confounded with additional challenges. Improved relief of cancer pain might require pharmacologic and non- 
pharmacologic antagonism of mechanisms in the neuro-sensory system and mechanisms integral to cancer proliferation. Improved understanding and improved treatment for cancer pain will likely emerge from teams of investigators. Clinicians, neuroscientists, cancer and cell biologists and psychologist studying the problem at the molecular, preclinical or patient level will undoubtedly be required to tackle the problem.

\section{Acknowledgments}

Erik Dillinger created the artwork for this review.

\section{Funding}

The author disclosed receipt of the following financial support for the research, authorship, and/or publication of this article: Work in the author's laboratory was supported by the National Institutes of Health/National Institute of Dental and Craniofacial Research (Grant Nos. R01DE019796 and R21DE018561).

\section{References}

Asai H, Ozaki N, Shinoda M, Nagamine K, Tohnai I, Ueda M, et al. Heat and mechanical hyperalgesia in mice model of cancer pain. Pain. 2005; 117:19-29. [PubMed: 16043290]

Bali KK, Venkataramani V, Satagopam VP, Gupta P, Schneider R, Kuner R. Transcriptional mechanisms underlying sensitization of peripheral sensory neurons by granulocyte-/granulocytemacrophage colony stimulating factors. Mol Pain. 2013; 9:48. [PubMed: 24067145]

Bapat AA, Hostetter G, Von Hoff DD, Han H. Perineural invasion and associated pain in pancreatic cancer. Nat Rev Cancer. 2011; 11:695-707. [PubMed: 21941281]

Bell RF, Eccleston C, Kalso EA. Ketamine as an adjuvant to opioids for cancer pain. Cochrane Database Syst Rev. 2012; 11:CD003351. [PubMed: 23152217]

Betourne A, Familiades J, Lacassagne L, Halley H, Cazales M, Ducommun B, et al. Decreased motivational properties of morphine in mouse models of cancerous- or inflammatory-chronic pain: implication of supraspinal neuropeptide FF(2) receptors. Neuroscience. 2008; 157:12-21. [PubMed: 18804517]

Bloom AP, Jimenez-Andrade JM, Taylor RN, Castaneda-Corral G, Kaczmarska MJ, Freeman KT, et al. Breast cancer-induced bone remodeling, skeletal pain, and sprouting of sensory nerve fibers. $\mathrm{J}$ Pain. 2011; 12:698-711. [PubMed: 21497141]

Brener S, Gonzalez-Moles MA, Tostes D, Esteban F, Gil-Montoya JA, Ruiz-Avila I, et al. A role for the substance P/NK-1 receptor complex in cell proliferation in oral squamous cell carcinoma. Anticancer Res. 2009; 29:2323-9. [PubMed: 19528498]

Cain DM, Wacnik PW, Turner M, Wendelschafer-Crabb G, Kennedy WR, Wilcox GL, et al. Functional interactions between tumor and peripheral nerve: changes in excitability and morphology of primary afferent fibers in a murine model of cancer pain. J Neurosci. 2001; 21:9367-76. [PubMed: 11717370]

Cao L, Liu X, Lin EJ, Wang C, Choi EY, Riban V, et al. Environmental and genetic activation of a brain-adipocyte BDNF/leptin axis causes cancer remission and inhibition. Cell. 2010; 142:52-64. [PubMed: 20603014]

Chizhmakov I, Mamenko N, Volkova T, Khasabova I, Simone DA, Krishtal O. P2X receptors in sensory neurons co-cultured with cancer cells exhibit a decrease in opioid sensitivity. Eur J Neurosci. 2009; 29:76-86. [PubMed: 19077126]

Constantin CE, Mair N, Sailer CA, Andratsch M, Xu ZZ, Blumer MJ, et al. Endogenous tumor necrosis factor alpha $(\mathrm{TNF}$ ) requires TNF receptor type 2 to generate heat hyperalgesia in a mouse cancer model. J Neurosci. 2008; 28:5072-81. [PubMed: 18463260]

Curto-Reyes V, Llames S, Hidalgo A, Menendez L, Baamonde A. Spinal and peripheral analgesic effects of the CB2 cannabinoid receptor agonist AM1241 in two models of bone cancer-induced pain. Br J Pharmacol. 2010; 160:561-73. [PubMed: 20233215] 
Donovan-Rodriguez T, Dickenson AH, Urch CE. Gabapentin normalizes spinal neuronal responses that correlate with behavior in a rat model of cancer-induced bone pain. Anesthesiology. 2005; 102:132-40. [PubMed: 15618797]

Donovan-Rodriguez T, Urch CE, Dickenson AH. Evidence of a role for descending serotonergic facilitation in a rat model of cancer-induced bone pain. Neurosci Lett. 2006; 393:237-42. [PubMed: 16256273]

Feng F, Yang J, Tong L, Yuan S, Tian Y, Hong L, et al. Substance P immunoreactive nerve fibres are related to gastric cancer differentiation status and could promote proliferation and migration of gastric cancer cells. Cell Biol Int. 2011; 35:623-9. [PubMed: 21091434]

Fujita M, Andoh T, Ohashi K, Akira A, Saiki I, Kuraishi Y. Roles of kinin B1 and B2 receptors in skin cancer pain produced by orthotopic melanoma inoculation in mice. Eur J Pain. 2010; 14:588-94. [PubMed: 19932979]

Furuse S, Kawamata T, Yamamoto J, Niiyama Y, Omote K, Watanabe M, et al. Reduction of bone cancer pain by activation of spinal cannabinoid receptor 1 and its expression in the superficial dorsal horn of the spinal cord in a murine model of bone cancer pain. Anesthesiology. 2009; 111:173-86. [PubMed: 19512863]

Gao YJ, Cheng JK, Zeng Q, Xu ZZ, Decosterd I, Xu X, et al. Selective inhibition of JNK with a peptide inhibitor attenuates pain hypersensitivity and tumor growth in a mouse skin cancer pain model. Exp Neurol. 2009; 219:146-55. [PubMed: 19445931]

Geis C, Graulich M, Wissmann A, Hagenacker T, Thomale J, Sommer C, et al. Evoked pain behavior and spinal glia activation is dependent on tumor necrosis factor receptor 1 and 2 in a mouse model of bone cancer pain. Neuroscience. 2010; 169:463-74. [PubMed: 20417692]

Ghilardi JR, Rohrich H, Lindsay TH, Sevcik MA, Schwei MJ, Kubota K, et al. Selective blockade of the capsaicin receptor TRPV1 attenuates bone cancer pain. J Neurosci. 2005; 25:3126-31. [PubMed: 15788769]

Gilchrist LS, Cain DM, Harding-Rose C, Kov AN, Wendelschafer-Crabb G, Kennedy WR, et al. Reorganization of P2X3 receptor localization on epidermal nerve fibers in a murine model of cancer pain. Brain Res. 2005; 1044:197-205. [PubMed: 15885218]

Gu X, Mei F, Liu Y, Zhang R, Zhang J, Ma Z. Intrathecal administration of the cannabinoid 2 receptor agonist JWH015 can attenuate cancer pain and decrease mRNA expression of the 2B subunit of $N$ methyl-D-aspartic acid. Anesth Analg. 2011; 113:405-11. [PubMed: 21519057]

Gu X, Zhang J, Ma Z, Wang J, Zhou X, Jin Y, et al. The role of $N$-methyl-D-aspartate receptor subunit NR2B in spinal cord in cancer pain. Eur J Pain. 2010; 14:496-502. [PubMed: 19815434]

Guerrero AV, Quang P, Dekker N, Jordan RC, Schmidt BL. Peripheral cannabinoids attenuate carcinoma-induced nociception in mice. Neurosci Lett. 2008; 433:77-81. [PubMed: 18242856]

Hald A, Ding M, Egerod K, Hansen RR, Konradsen D, Jorgensen SG, et al. Differential effects of repeated low dose treatment with the cannabinoid agonist WIN 55,212-2 in experimental models of bone cancer pain and neuropathic pain. Pharmacol Biochem Behav. 2008; 91:38-46. [PubMed: 18611408]

Hald A, Hansen RR, Thomsen MW, Ding M, Croucher PI, Gallagher O, et al. Cancer-induced bone loss and associated pain-related behavior is reduced by risedronate but not its phosphonocarboxylate analog NE-10790. Int J Cancer. 2009; 125:1177-85. [PubMed: 19444917]

Hald A, Nedergaard S, Hansen RR, Ding M, Heegaard AM. Differential activation of spinal cord glial cells in murine models of neuropathic and cancer pain. Eur J Pain. 2009; 13:138-45. [PubMed: 18499488]

Halvorson KG, Kubota K, Sevcik MA, Lindsay TH, Sotillo JE, Ghilardi JR, et al. A blocking antibody to nerve growth factor attenuates skeletal pain induced by prostate tumor cells growing in bone. Cancer Res. 2005; 65:9426-35. [PubMed: 16230406]

Halvorson KG, Sevcik MA, Ghilardi JR, Sullivan LJ, Koewler NJ, Bauss F, et al. Intravenous ibandronate rapidly reduces pain, neurochemical indices of central sensitization, tumor burden, and skeletal destruction in a mouse model of bone cancer. J Pain Symptom Manage. 2008; 36:289-303. [PubMed: 18411018] 
Hamamoto DT, Giridharagopalan S, Simone DA. Acute and chronic administration of the cannabinoid receptor agonist CP 55,940 attenuates tumor-evoked hyperalgesia. Eur J Pharmacol. 2007; 558:73-87. [PubMed: 17250825]

Han Y, Li Y, Xiao X, Liu J, Meng XL, Liu FY, et al. Formaldehyde up-regulates TRPV1 through MAPK and PI3K signaling pathways in a rat model of bone cancer pain. Neurosci Bull. 2012; 28:165-72. [PubMed: 22466127]

Hang LH, Yang JP, Yin W, Wang LN, Guo F, Ji FH, et al. Activation of spinal TDAG8 and its downstream PKA signaling pathway contribute to bone cancer pain in rats. Eur J Neurosci. 2012; 36:2107-17. [PubMed: 22515300]

Hans G, Schmidt BL, Strichartz G. Nociceptive sensitization by endothelin-1. Brain Res Rev. 2009; 60:36-42. [PubMed: 19150466]

Harano N, Ono K, Hidaka K, Kai A, Nakanishi O, Inenaga K. Differences between orofacial inflammation and cancer pain. J Dent Res. 2010; 89:615-20. [PubMed: 20332329]

Hardt M, Lam DK, Dolan JC, Schmidt BL. Surveying proteolytic processes in human cancer microenvironments by microdialysis and activity-based mass spectrometry. Proteomics Clin Appl. 2011; 5:636-43. [PubMed: 22262628]

Honore P, Chandran P, Hernandez G, Gauvin DM, Mikusa JP, Zhong C, et al. Repeated dosing of ABT-102, a potent and selective TRPV1 antagonist, enhances TRPV1-mediated analgesic activity in rodents, but attenuates antagonist-induced hyperthermia. Pain. 2009; 142:27-35. [PubMed: 19135797]

Honore P, Luger NM, Sabino MA, Schwei MJ, Rogers SD, Mach DB, et al. Osteoprotegerin blocks bone cancer-induced skeletal destruction, skeletal pain and pain-related neurochemical reorganization of the spinal cord. Nat Med. 2000; 6:521-8. [PubMed: 10802707]

Honore P, Rogers SD, Schwei MJ, Salak-Johnson JL, Luger NM, Sabino MC, et al. Murine models of inflammatory, neuropathic and cancer pain each generates a unique set of neurochemical changes in the spinal cord and sensory neurons. Neuroscience. 2000; 98:585-98. [PubMed: 10869852]

$\mathrm{Hu}$ JH, Wu MY, Tao M, Yang JP. Changes in protein expression and distribution of spinal CCR2 in a rat model of bone cancer pain. Brain Res. 2013; 1509:1-7. [PubMed: 23511129]

Huang JL, Chen XL, Guo C, Wang YX. Contributions of spinal D-amino acid oxidase to bone cancer pain. Amino Acids. 2012; 43:1905-1918. [PubMed: 22996731]

Ibrahim MM, Porreca F, Lai J, Albrecht PJ, Rice FL, Khodorova A, Davar G, Makriyannis A, Vanderah TW, Mata HP, Malan TP Jr. CB2 cannabinoid receptor activation produces antinociception by stimulating peripheral release of endogenous opioids. Proc Natl Acad Sci U S A. 2005; 102:3093-3098. [PubMed: 15705714]

Jimenez-Andrade JM, Ghilardi JR, Castaneda-Corral G, Kuskowski MA, Mantyh PW. Preventive or late administration of anti-NGF therapy attenuates tumor-induced nerve sprouting, neuroma formation, and cancer pain. Pain. 2011; 152:2564-74. [PubMed: 21907491]

Joseph EK, Green PG, Bogen O, Alvarez P, Levine JD. Vascular endothelial cells mediate mechanical stimulation-induced enhancement of endothelin hyperalgesia via activation of $\mathrm{P} 2 \mathrm{X} 2 / 3$ receptors on nociceptors. J Neurosci. 2013; 33:2849-59. [PubMed: 23407944]

Kaan TK, Yip PK, Patel S, Davies M, Marchand F, Cockayne DA, et al. Systemic blockade of P2X3 and P2X2/3 receptors attenuates bone cancer pain behaviour in rats. Brain. 2010; 133:2549-64. [PubMed: 20802203]

Karai L, Brown DC, Mannes AJ, Connelly ST, Brown J, Gandal M, et al. Deletion of vanilloid receptor 1-expressing primary afferent neurons for pain control. J Clin Invest 2004. 2004; 113:1344-52.

Kehl LJ, Hamamoto DT, Wacnik PW, Croft DL, Norsted BD, Wilcox GL, et al. A cannabinoid agonist differentially attenuates deep tissue hyperalgesia in animal models of cancer and inflammatory muscle pain. Pain. 2003; 103:175-86. [PubMed: 12749972]

Khasabov SG, Hamamoto DT, Harding-Rose C, Simone DA. Tumor-evoked hyperalgesia and sensitization of nociceptive dorsal horn neurons in a murine model of cancer pain. Brain Res. 2007; 1180:7-19. [PubMed: 17935703] 
Khasabova IA, Chandiramani A, Harding-Rose C, Simone DA, Seybold VS. Increasing 2arachidonoyl glycerol signaling in the periphery attenuates mechanical hyperalgesia in a model of bone cancer pain. Pharmacol Res. 2011a; 64:60-7. [PubMed: 21440630]

Khasabova IA, Gielissen J, Chandiramani A, Harding-Rose C, Odeh DA, Simone DA, et al. CB1 and CB2 receptor agonists promote analgesia through synergy in a murine model of tumor pain. Behav Pharmacol. 2011b; 22:607-16. [PubMed: 21610490]

Khasabova IA, Holman M, Morse T, Burlakova N, Coicou L, Harding-Rose C, et al. Increased anandamide uptake by sensory neurons contributes to hyperalgesia in a model of cancer pain. Neurobiol Dis. 2013; 58C:19-28. [PubMed: 23644187]

Khasabova IA, Khasabov SG, Harding-Rose C, Coicou LG, Seybold BA, Lindberg AE, et al. A decrease in anandamide signaling contributes to the maintenance of cutaneous mechanical hyperalgesia in a model of bone cancer pain. J Neurosci. 2008; 28:11141-52. [PubMed: 18971457]

Khasabova IA, Stucky CL, Harding-Rose C, Eikmeier L, Beitz AJ, Coicou LG, et al. Chemical interactions between fibrosarcoma cancer cells and sensory neurons contribute to cancer pain. $\mathrm{J}$ Neurosci. 2007; 27:10289-98. [PubMed: 17881535]

Kim WM, Jeong CW, Lee SH, Kim YO, Cui JH, Yoon MH. The intrathecally administered kappa-2 opioid agonist GR89696 and interleukin-10 attenuate bone cancer-induced pain through synergistic interaction. Anesth Analg. 2011; 113:934-40. [PubMed: 21788320]

King TE, Pawar SC, Majuta L, Sroka IC, Wynn D, Demetriou MC, et al. The role of alpha 6 integrin in prostate cancer migration and bone pain in a novel xenograft model. PLoS One. 2008; 3:e3535. [PubMed: 18958175]

Kuraishi Y, Iida Y, Zhang HW, Uehara S, Nojima H, Murata J, et al. Suppression by gabapentin of pain-related mechano-responses in mice given orthotopic tumor inoculation. Biol Pharm Bull. 2003; 26:550-2. [PubMed: 12673042]

Kwak EL, Bang YJ, Camidge DR, Shaw AT, Solomon B, Maki RG, et al. Anaplastic lymphoma kinase inhibition in non-small-cell lung cancer. N Engl J Med. 2010; 363:1693-703. [PubMed: 20979469]

Lam DK, Dang D, Zhang J, Dolan JC, Schmidt BL. Novel animal models of acute and chronic cancer pain: a pivotal role for PAR2. J Neurosci 2012. 2012; 32:14178-83.

Lam DK, Schmidt BL. Serine proteases and protease-activated receptor 2-dependent allodynia: a novel cancer pain pathway. Pain. 2010; 149:263-72. [PubMed: 20189717]

Lan LS, Ping YJ, Na WL, Miao J, Cheng QQ, Ni MZ, et al. Down-regulation of Toll-like receptor 4 gene expression by short interfering RNA attenuates bone cancer pain in a rat model. Mol Pain. 2010; 6:2. [PubMed: 20089147]

Lautner MA, Ruparel SB, Patil MJ, Hargreaves KM. In vitro sarcoma cells release a lipophilic substance that activates the pain transduction system via TRPV1. Ann Surg Oncol. 2011; 18:86671. [PubMed: 20842457]

Li X, Wang XW, Feng XM, Zhou WJ, Wang YQ, Mao-Ying QL. Stage-dependent anti-allodynic effects of intrathecal Toll-like receptor 4 antagonists in a rat model of cancer induced bone pain. $J$ Physiol Sci. 2013; 63:203-9. [PubMed: 23392901]

Lihua P, Su M, Zejun Z, Ke W, Bennett MI. Spinal cord stimulation for cancer-related pain in adults. Cochrane Database Syst Rev. 2013; 2:CD009389. [PubMed: 23450600]

Liu J, Liu FY, Tong ZQ, Li ZH, Chen W, Luo WH. Lysine-specific demethylase 1 in breast cancer cells contributes to the production of endogenous formaldehyde in the meta-static bone cancer pain model of rats. PLoS One. 2013; 8:e58957. [PubMed: 23516587]

Liu S, Liu WT, Liu YP, Dong HL, Henkemeyer M, Xiong LZ, et al. Blocking EphB1 receptor forward signaling in spinal cord relieves bone cancer pain and rescues analgesic effect of morphine treatment in rodents. Cancer Res. 2011; 71:4392-402. [PubMed: 21555368]

Lozano-Ondoua AN, Wright C, Vardanyan A, King T, Largent-Milnes TM, Nelson M, et al. A cannabinoid 2 receptor agonist attenuates bone cancer-induced pain and bone loss. Life Sci. 2010; 86:646-53. [PubMed: 20176037]

Magnon C, Hall SJ, Lin J, Xue X, Gerber L, Freedland SJ, et al. Autonomic nerve development contributes to prostate cancer progression. Science. 2013; 341:1236361. [PubMed: 23846904] 
Mantyh WG, Jimenez-Andrade JM, Stake JI, Bloom AP, Kaczmarska MJ, Taylor RN, et al. Blockade of nerve sprouting and neuroma formation markedly attenuates the development of late stage cancer pain. Neuroscience. 2010; 171:588-98. [PubMed: 20851743]

Mapp PI, Walsh DA. Mechanisms and targets of angiogenesis and nerve growth in osteoarthritis. Nat Rev Rheumatol. 2012; 8:390-8. [PubMed: 22641138]

Mayordomo C, Garcia-Recio S, Ametller E, Fernandez-Nogueira P, Pastor-Arroyo EM, Vinyals L, et al. Targeting of substance P induces cancer cell death and decreases the steady state of EGFR and Her2. J Cell Physiol. 2012; 227:1358-66. [PubMed: 21604273]

Mercadante S, Giarratano A. The long and winding road of non steroidal antinflammatory drugs and paracetamol in cancer pain management: a critical review. Crit Rev Oncol Hematol. 2013; 87:140-5. [PubMed: 23395343]

Nagae M, Hiraga T, Yoneda T. Acidic microenvironment created by osteoclasts causes bone pain associated with tumor colonization. J Bone Miner Metab. 2007; 25:99-104. [PubMed: 17323179]

Nagamine K, Ozaki N, Shinoda M, Asai H, Nishiguchi H, Mitsudo K, et al. Mechanical allodynia and thermal hyperalgesia induced by experimental squamous cell carcinoma of the lower gingiva in rats. J Pain. 2006; 7:659-70. [PubMed: 16942952]

Neumann E. Secondare cancroid infiltration des nervus mentalis bei einem. Arch Pathol Anat. 1862; 24:201.

Nico B, Mangieri D, Benagiano V, Crivellato E, Ribatti D. Nerve growth factor as an angiogenic factor. Microvasc Res. 2008; 75:135-41. [PubMed: 17764704]

Niiyama Y, Kawamata T, Yamamoto J, Furuse S, Namiki A. SB366791, a TRPV1 antagonist, potentiates analgesic effects of systemic morphine in a murine model of bone cancer pain. $\mathrm{Br} \mathrm{J}$ Anaesth. 2009; 102:251-8. [PubMed: 19038965]

Ono K, Harano N, Nagahata S, Seta Y, Tsujisawa T, Inenaga K, et al. Behavioral characteristics and cFos expression in the medullary dorsal horn in a rat model for orofacial cancer pain. Eur J Pain. 2009; 13:373-9. [PubMed: 18599327]

Paley CA, Johnson MI, Tashani OA, Bagnall AM. Acupuncture for cancer pain in adults. Cochrane Database Syst Rev. 2011; (1):CD007753. [PubMed: 21249694]

Portenoy RK, Ganae-Motan ED, Allende S, Yanagihara R, Shaiova L, Weinstein S, et al. Nabiximols for opioid-treated cancer patients with poorly-controlled chronic pain: a randomized, placebocontrolled, graded-dose trial. J Pain. 2012; 13:438-49. [PubMed: 22483680]

Potenzieri C, Harding-Rose C, Simone DA. The cannabinoid receptor agonist, WIN 55, 212-2, attenuates tumor-evoked hyperalgesia through peripheral mechanisms. Brain Res. 2008; 1215:6975. [PubMed: 18486111]

Qiu F, Jiang Y, Zhang H, Liu Y, Mi W. Increased expression of tetrodotoxin-resistant sodium channels Nav1.8 and Nav1.9 within dorsal root ganglia in a rat model of bone cancer pain. Neurosci Lett. 2012; 512:61-6. [PubMed: 22342308]

Radtke C, Vogt PM, Devor M, Kocsis JD. Keratinocytes acting on injured afferents induce extreme neuronal hyper-excitability and chronic pain. Pain. 2010; 148:94-102. [PubMed: 19932564]

Rakvag TT, Ross JR, Sato H, Skorpen F, Kaasa S, Klepstad P. Genetic variation in the catechol-Omethyltransferase (COMT) gene and morphine requirements in cancer patients with pain. Mol Pain. 2008; 4:64. [PubMed: 19094200]

Ren BX, Gu XP, Zheng YG, Liu CL, Wang D, Sun YE, et al. Intrathecal injection of metabotropic glutamate receptor subtype 3 and 5 agonist/antagonist attenuates bone cancer pain by inhibition of spinal astrocyte activation in a mouse model. Anesthesiology. 2012; 116:122-32. [PubMed: 22123524]

Sabino MA, Ghilardi JR, Jongen JL, Keyser CP, Luger NM, Mach DB, et al. Simultaneous reduction in cancer pain, bone destruction, and tumor growth by selective inhibition of cyclooxygenase-2. Cancer Res. 2002; 62:7343-9. [PubMed: 12499278]

Sabino MA, Luger NM, Mach DB, Rogers SD, Schwei MJ, Mantyh PW. Different tumors in bone each give rise to a distinct pattern of skeletal destruction, bone cancer-related pain behaviors and neurochemical changes in the central nervous system. Int J Cancer. 2003; 104:550-8. [PubMed: 12594809] 
Saghafi N, Lam DK, Schmidt BL. Cannabinoids attenuate cancer pain and proliferation in a mouse model. Neurosci Lett. 2011; 488:247-51. [PubMed: 21094209]

Sago T, Ono K, Harano N, Furuta-Hidaka K, Hitomi S, Nunomaki M, et al. Distinct time courses of microglial and astrocytic hyperactivation and the glial contribution to pain hypersensitivity in a facial cancer model. Brain Res. 2012; 1457:70-80. [PubMed: 22537829]

Schwei MJ, Honore P, Rogers SD, Salak-Johnson JL, Finke MP, Ramnaraine ML, et al. Neurochemical and cellular reorganization of the spinal cord in a murine model of bone cancer pain. J Neurosci. 1999; 19:10886-97. [PubMed: 10594070]

Sevcik MA, Ghilardi JR, Halvorson KG, Lindsay TH, Kubota K, Mantyh PW. Analgesic efficacy of bradykinin B1 antagonists in a murine bone cancer pain model. J Pain. 2005; 6:771-5. [PubMed: 16275602]

Sevcik MA, Ghilardi JR, Peters CM, Lindsay TH, Halvorson KG, Jonas BM, et al. Anti-NGF therapy profoundly reduces bone cancer pain and the accompanying increase in markers of peripheral and central sensitization. Pain. 2005; 115:128-41. [PubMed: 15836976]

Shimoyama M, Tanaka K, Hasue F, Shimoyama N. A mouse model of neuropathic cancer pain. Pain. 2002; 99:167-74. [PubMed: 12237194]

Shimoyama M, Tatsuoka H, Ohtori S, Tanaka K, Shimoyama N. Change of dorsal horn neurochemistry in a mouse model of neuropathic cancer pain. Pain. 2005; 114:221-30. [PubMed: 15733648]

Shinoda M, Ogino A, Ozaki N, Urano H, Hironaka K, Yasui M, et al. Involvement of TRPV1 in nociceptive behavior in a rat model of cancer pain. J Pain. 2008; 9:687-99. [PubMed: 18455478]

Smeester BA, Al-Gizawiy M, Beitz AJ. Effects of different electroacupuncture scheduling regimens on murine bone tumor-induced hyperalgesia: sex differences and role of inflammation. Evid Based Complement Alternat Med. 2012; 2012:671386. [PubMed: 23320035]

Stock K, Kumar J, Synowitz M, Petrosino S, Imperatore R, Smith ES, et al. Neural precursor cells induce cell death of high-grade astrocytomas through stimulation of TRPV1. Nat Med. 2012; 18:1232-8. [PubMed: 22820645]

Suzuki M, Narita M, Hasegawa M, Furuta S, Kawamata T, Ashikawa M, et al. Sensation of abdominal pain induced by peritoneal carcinomatosis is accompanied by changes in the expression of substance $\mathrm{P}$ and mu-opioid receptors in the spinal cord of mice. Anesthesiology. 2012; 117:84756. [PubMed: 22913923]

Szabo T, Olah Z, Iadarola MJ, Blumberg PM. Epidural resiniferatoxin induced prolonged regional analgesia to pain. Brain Res. 1999; 840:92-8. [PubMed: 10517956]

Tong W, Wang W, Huang J, Ren N, Wu SX, Li YQ. Spinal high-mobility group box 1 contributes to mechanical allodynia in a rat model of bone cancer pain. Biochem Biophys Res Commun. 2010; 395:572-6. [PubMed: 20399746]

Urch CE, Donovan-Rodriguez T, Dickenson AH. Alterations in dorsal horn neurones in a rat model of cancer-induced bone pain. Pain. 2003; 106:347-56. [PubMed: 14659517]

Urch CE, Donovan-Rodriguez T, Gordon-Williams R, Bee LA, Dickenson AH. Efficacy of chronic morphine in a rat model of cancer-induced bone pain: behavior and in dorsal horn pathophysiology. J Pain. 2005; 6:837-45. [PubMed: 16326372]

Vachon P, Millecamps M, Low L, Thompsosn SJ, Pailleux F, Beaudry F, et al. Alleviation of chronic neuropathic pain by environmental enrichment in mice well after the establishment of chronic pain. Behav Brain Funct sssssssss. 2013; 9:22.

van den Beuken-van Everdingen MH, de Rijke JM, Kessels AG, Schouten HC, van Kleef M, Patijn J. Prevalence of pain in patients with cancer: a systematic review of the past 40 years. Ann Oncol. 2007; 18:1437-49. [PubMed: 17355955]

Vanhecke E, Adriaenssens E, Verbeke S, Meignan S, Germain E, Berteaux N, et al. Brain-derived neurotrophic factor and neurotrophin-4/5 are expressed in breast cancer and can be targeted to inhibit tumor cell survival. Clin Cancer Res. 2011; 17:1741-52. [PubMed: 21350004]

Vit JP, Ohara PT, Tien DA, Fike JR, Eikmeier L, Beitz A, et al. The analgesic effect of low dose focal irradiation in a mouse model of bone cancer is associated with spinal changes in neuro-mediators of nociception. Pain. 2006; 120:188-201. [PubMed: 16360279] 
Wacnik PW, Baker CM, Herron MJ, Kren BT, Blazar BR, Wilcox GL, et al. Tumor-induced mechanical hyperalgesia involves CGRP receptors and altered innervation and vascularization of DsRed2 fluorescent hindpaw tumors. Pain. 2005; 115:95-106. [PubMed: 15836973]

Wacnik PW, Eikmeier LJ, Ruggles TR, Ramnaraine ML, Walcheck BK, Beitz AJ, et al. Functional interactions between tumor and peripheral nerve: morphology, algogen identification, and behavioral characterization of a new murine model of cancer pain. J Neurosci. 2001; 21:9355-66. [PubMed: 11717369]

Wacnik PW, Kehl LJ, Trempe TM, Ramnaraine ML, Beitz AJ, Wilcox GL. Tumor implantation in mouse humerus evokes movement-related hyperalgesia exceeding that evoked by intramuscular carrageenan. Pain. 2003; 101:175-86. [PubMed: 12507712]

Wang XW, Hu S, Mao-Ying QL, Li Q, Yang CJ, Zhang H, et al. Activation of c-jun N-terminal kinase in spinal cord contributes to breast cancer induced bone pain in rats. Mol Brain. 2012a; 5:21. [PubMed: 22681856]

Wang XW, Li TT, Zhao J, Mao-Ying QL, Zhang H, Hu S, et al. Extracellular signal-regulated kinase activation in spinal astrocytes and microglia contributes to cancer-induced bone pain in rats. Neuroscience. 2012b; 217:172-81. [PubMed: 22564552]

Wu JX, Xu MY, Miao XR, Lu ZJ, Yuan XM, Li XQ, et al. Functional up-regulation of P2X3 receptors in dorsal root ganglion in a rat model of bone cancer pain. Eur J Pain. 2012; 16:1378-88. [PubMed: 22528605]

Yamamoto J, Kawamata T, Niiyama Y, Omote K, Namiki A. Down-regulation of mu opioid receptor expression within distinct subpopulations of dorsal root ganglion neurons in a murine model of bone cancer pain. Neuroscience. 2008; 151:843-53. [PubMed: 18178319]

Yanagisawa Y, Furue H, Kawamata T, Uta D, Yamamoto J, Furuse S, et al. Bone cancer induces a unique central sensitization through synaptic changes in a wide area of the spinal cord. Mol Pain. 2010; 6:38. [PubMed: 20602757]

Yao M, Chang XY, Chu YX, Yang JP, Wang LN, Cao HQ, et al. Antiallodynic effects of propentofylline Elicited by interrupting spinal glial function in a rat model of bone cancer pain. $\mathbf{J}$ Neurosci Res. 2011; 89:1877-86. [PubMed: 21812015]

Ye Y, Dang D, Viet CT, Dolan JC, Schmidt BL. Analgesia targeting IB4-positive neurons in cancerinduced mechanical hypersensitivity. J Pain. 2012; 13:524-31. [PubMed: 22483679]

Ye Y, Dang D, Zhang J, Viet CT, Lam DK, Dolan JC, et al. Nerve growth factor links oral cancer progression, pain, and cachexia. Mol Cancer Ther. 2011; 10:1667-76. [PubMed: 21750223]

Yin Q, Cheng W, Cheng MY, Fan SZ, Shen W. Intrathecal injection of anti-CX3CR1 neutralizing antibody delayed and attenuated pain facilitation in rat tibial bone cancer pain model. Behav Pharmacol. 2010; 21:595-601. [PubMed: 20736819]

Zeppetella G, Davies AN. Opioids for the management of breakthrough pain in cancer patients. Cochrane Database Syst Rev. 2013; 10:CD004311. [PubMed: 24142465]

Zhang RX, Li A, Liu B, Wang L, Ren K, Qiao JT, et al. Electroacupuncture attenuates bone cancer pain and inhibits spinal interleukin-1- $\beta$ expression in a rat model. Anesth Analg. 2007; 105:1482-8. [PubMed: 17959986]

Zhang RX, Li A, Liu B, Wang L, Xin J, Ren K, et al. Electroacupuncture attenuates bone-cancerinduced hyperalgesia and inhibits spinal preprodynorphin expression in a rat model. Eur J Pain. 2008; 12:870-8. [PubMed: 18221900]

Zhang RX, Liu B, Wang L, Ren K, Qiao JT, Berman BM, et al. Spinal glial activation in a new rat model of bone cancer pain produced by prostate cancer cell inoculation of the tibia. Pain. 2005; 118:125-36. [PubMed: 16154703]

Zhang YK, Huang ZJ, Liu S, Liu YP, Song AA, Song XJ. WNT signaling underlies the pathogenesis of neuropathic pain in rodents. J Clin Invest. 2013; 123:2268-86. [PubMed: 23585476] 


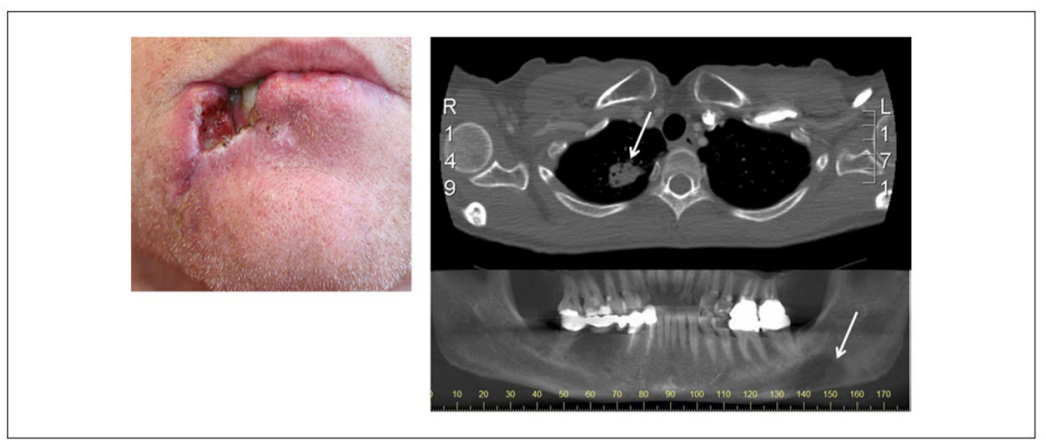

Figure 1.

Cancer pain can depend on the histologic type and the anatomic site involved. The patient pictured on the left has a lower lip squamous cell carcinoma. Despite significant pain he delayed his treatment. Ultimately, he sought treatment given his incapacity to eat, drink, or talk secondary to function-induced pain. On the right is an axial CT scan of a 52-year-old woman diagnosed with squamous cell carcinoma of the lung. Her initial complaint was pain in the jaw that turned out to be a metastasis of the lung cancer to her jaw. She had no pain in the lung. 


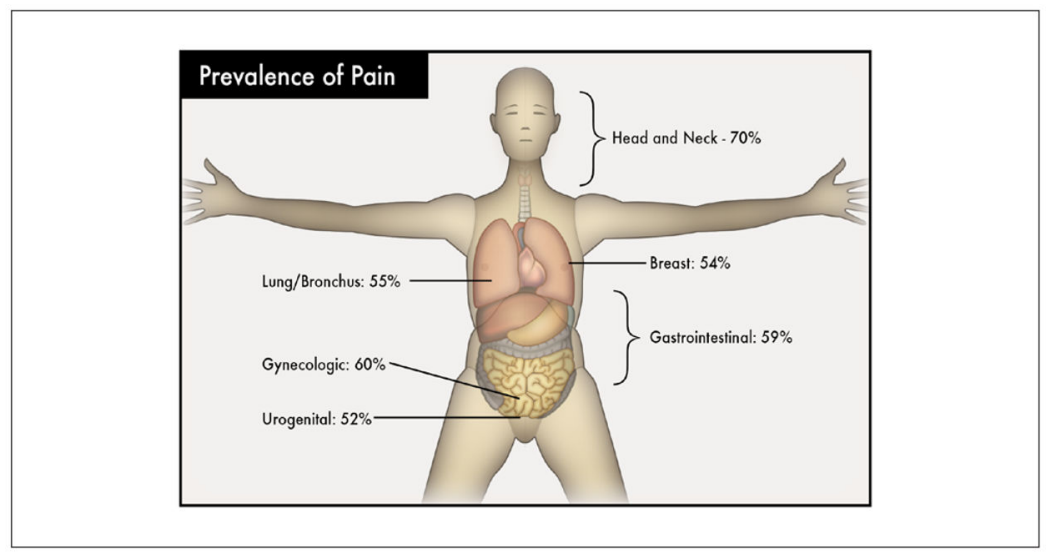

Figure 2.

The prevalence of pain based on the histologic type of cancer. The prevalence of pain is greater than 50\% for all types of cancer (van den Beuken-van Everdingen and others, 2007). 


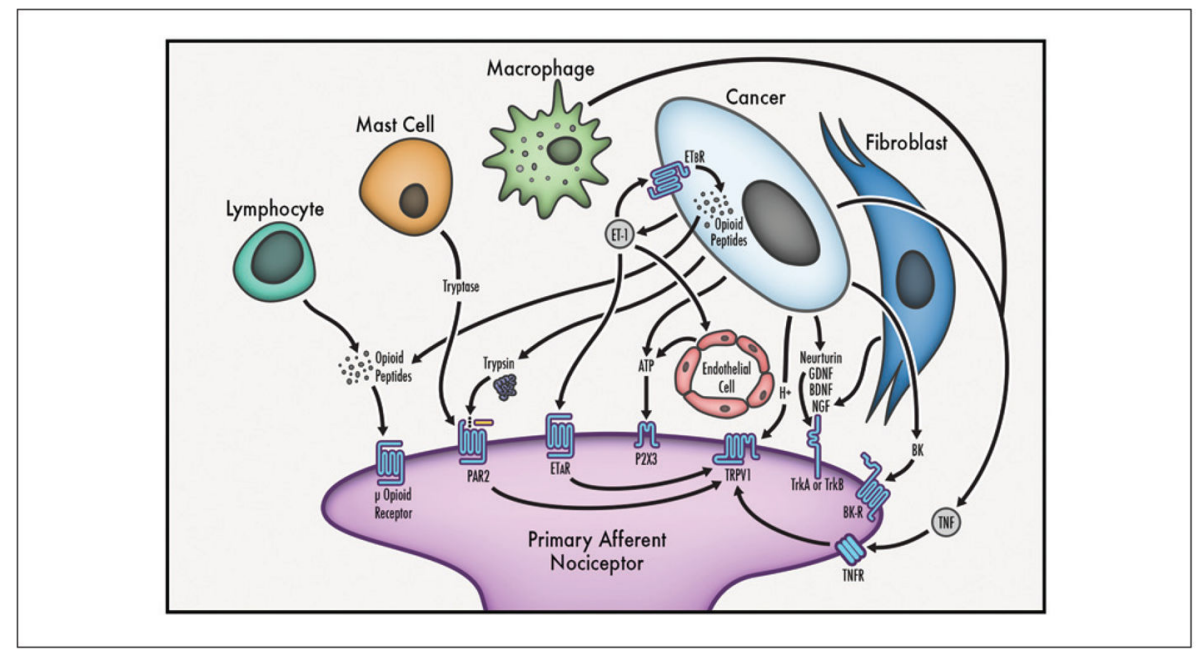

Figure 3.

A model of the cancer microenvironment and possible mechanisms that generate cancer pain. The primary hypothesis underlying cancer pain is that the cancer produces and secretes mediators that sensitize and/or activates primary afferent neurons within the microenvironment. Other constituent cells, which can be recruited by chemoattractants or mediators released by the cancer, including lymphocytes, mast cells, macrophages and fibroblasts also secrete mediators which modulate cancer pain. For example, in prostate cancer fibroblasts are responsible for secreting NGF. Mechanical stimulation of endothelial cells induces the release of ATP; this effect is sensitized by ET-1 (Joseph and others, 2013). Opioids can be secreted into the cancer microenvironment by the cancer or other cells including lymphocytes. BDNF = brain derived neurotrophic factor; $\mathrm{BK}=$ bradykinin; $\mathrm{BK}-\mathrm{R}$ $=$ bradykinin receptor; $\mathrm{ET}-1=$ endothelin-1; $\mathrm{ET}_{\mathrm{A}} \mathrm{R}=$ endothelin $\mathrm{A}$ receptor; $\mathrm{ET}_{\mathrm{B}} \mathrm{R}=$ endothelin $\mathrm{B}$ receptor; GDNF = glial derived neurotrophic factor; NGF $=$ nerve growth factor; $\mathrm{PAR} 2=$ protease activated receptor 2 ; $\operatorname{TrkA}=$ tyrosine kinase receptor $\mathrm{A} ; \operatorname{TrkB}=$ tyrosine kinase receptor B; TRPV1 = transient receptor potential vanilloid 1 . 


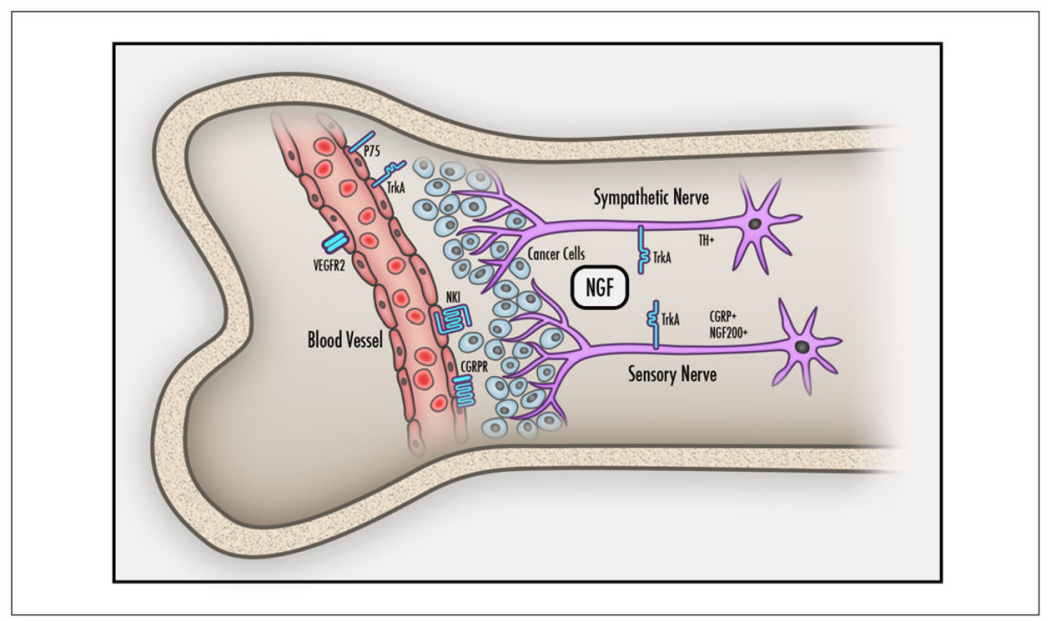

Figure 4.

Angiogenesis and neurogenesis in the cancer microenvironment are linked processes that contribute to cancer pain. Newly forming blood vessels and nerves interact on a molecular and anatomic basis. VEGF and NGF share common signal transduction pathways. NGF, which induces both angiogenesis and neurogenesis, is secreted by cancers or cancerassociated cells (Nico and others, 2008). Endothelial cells express the NGF receptors, p75 and TrkA receptor, as well as the receptor for VEGF, VEGFR2. SP and CGRP act on their respective receptors, NK1 and CGRPR, on blood vessels to induce endothelial cell proliferation and blood vessel formation. NGF acts through TrkA to generate sensory and sympathetic nerve fibers that innervate the cancer microenvironment; both fiber types contribute to cancer pain. $\mathrm{CGRP}=$ calcitonin gene-related protein; $\mathrm{CGRPR}=$ calcitonin gene related protein receptor; NGF, nerve growth factor; NK1 = neurokinin-1 receptor; $\mathrm{SP}=$ substance $\mathrm{P} ; \mathrm{TH}=$ tyrosine hydroxylase; TrkA = tyrosine kinase receptor $\mathrm{A}$; VEGF = vascular endothelial growth factor; VEGFR = vascular endothelial growth factor receptor. 


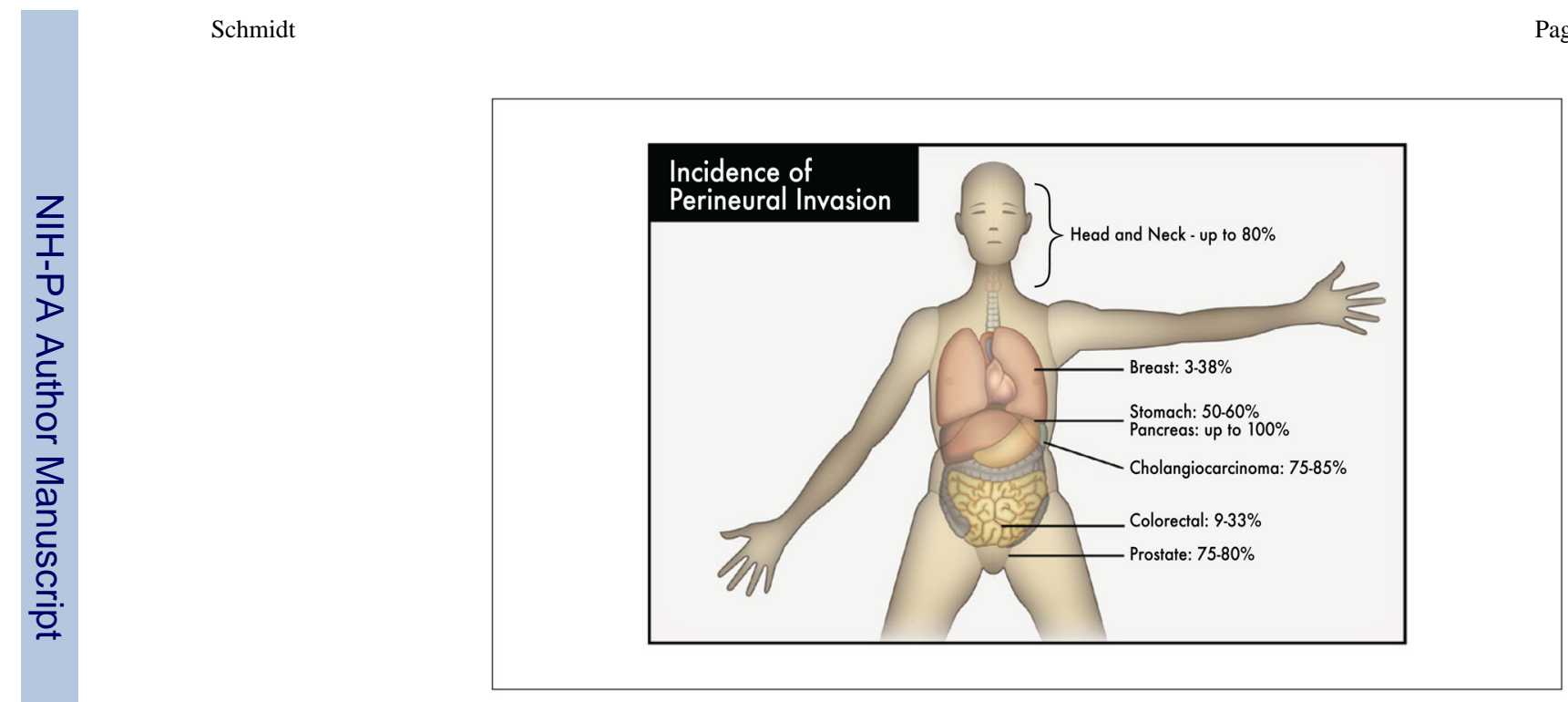

Figure 5.

The incidence of perineural invasion based on the anatomic location of cancer (Bapat and others, 2011). 


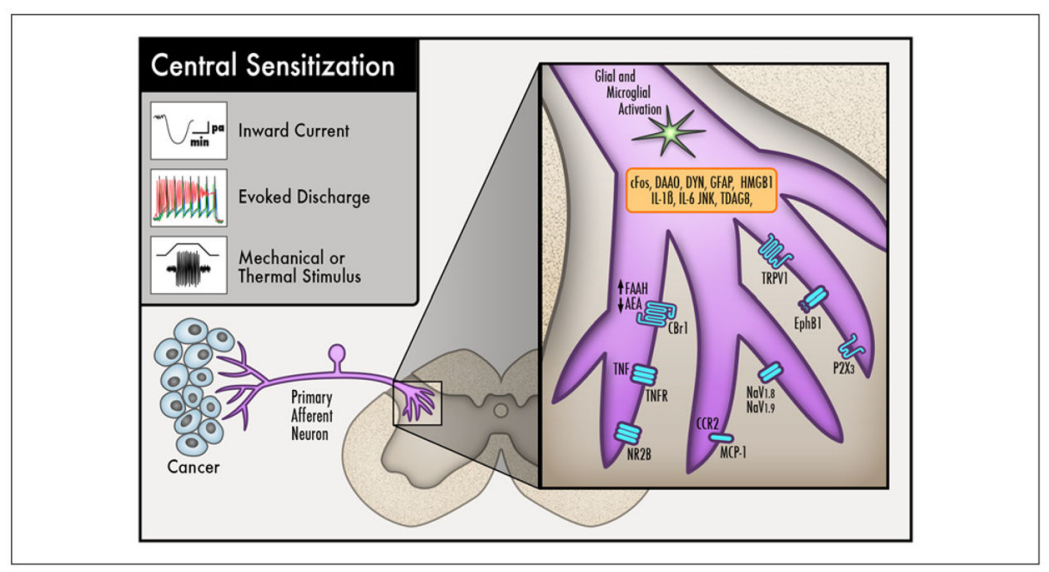

Figure 6.

Cancer induces spinal cord changes. Cancer leads to dorsal horn plasticity which includes up-regulation of pain-related mediators, up-regulation of pain-related receptors, glial and microglial activation, and electrophysiologic changes (i.e., greater amplitude of induced inward currents, evoked discharges, increased response of nociceptive neurons to heat and mechanical stimuli). The up-regulated nociceptive-related mediators are depicted in the orange oval. Cancer decreases AEA signaling through up-regulation of FAAH. The depicted changes are based on work from multiple cancer pain models. Please see the text for details and references. $\mathrm{AEA}=$ anandamide; $\mathrm{CBr} 1=$ cannabinoid receptor 1 ; $\mathrm{CCR} 2=$ chemokine $\mathrm{C}$ $\mathrm{C}$ motif receptor 2; DAAO = D-Amino acid oxidase; DYN = dynorphin; EphB1 = ephrin B ligand receptor; FAAH = fatty acid amide hydrolase; GFAP = glial fibrillary acidic protein; HMGB1 = high-mobility group protein 1; JNK = c-jun N-terminal kinase; MCP-1 = monocyte chemoattractant protein-1; NR2B = NMDA ( $N$-methyl-D-aspartate) receptor subunit; TDAG8 = T-cell death-associated gene 8; $\mathrm{TNF}=$ tumor necrosis factor; $\mathrm{TNFR}=$ tumor necrosis factor receptor; TRPV1 = transient receptor potential vanilloid 1. 